\section{BIBLI() \\ COUNS}

Biblio Couns I Jurnal Kajian Konseling dan Pendidikan

Vol. 1, No. 1, 2018, hlm. 12-16

Tersedia Online di jurnal.umsu.ac.id/index.php/biblio

ISSN 2620-3103 (online)

DOI: https://doi.org/10.30596/bibliocouns.v1i1.1943

\title{
Pengaruh Strategi Everyone Is A Teacher Here terhadap Motivasi Belajar Siswa
}

\author{
Grandi Impianti ${ }^{1}$, Jamila ${ }^{2}$ \\ ${ }^{1,2}$ Prodi Bimbingan dan Konseling Universitas Muhammadiyah Sumatera Utara \\ Jalan Muchtar Basri No. 3 Medan Timur \\ Korespondensi: jamila@umsu.ac.id
}

\begin{abstract}
The problem of this research is There Is Influence Everyone Is A Teacher Here Strategy on Student Motivation Class XI In SMK Muhammadiyah 04 Medan T.P 2016/2017. The purpose of this study is to determine the effect of Everyone Is A Teacher Here Strategy on Student Motivation Class XI In SMK Muhammadiyah 04 Medan TP 2016/2017 which amounted to 211 Students consisting of 6 classes and divided into 3 departments and the sample studied is class XI AK 2 SMK Muhammadiyah 04 Medan as many as 38 students. Instrument used is questionnaire and test. Which questionnaire is doing observations in SMK Muhammadiyah 04 Medan to know the motivation of student learning. The method used in this research is quantitative method with product moment analysis unit. From the results of this study can be seen improving student learning motivation by using the influence of Everyone Is A Teacher Here strategy on the subject of Citizenship Education with research conducted, it was found that Everyone Is A Teacher Here learning affects the motivation of student learning on the subject of Citizenship Education. From the results of the hypothesis calculation obtained tcount $=2.309$ for the significant level $\alpha=0.05$ and $d k=n-2=38-2=36$, then obtained the price $r$ table $=1.6892$. Obtained tcount 2.309> ttabel 1.6892, this means Ha accepted means a significant influence between strategy Everyone Is A Teacher Here on student learning motivation.
\end{abstract}

Keywords: Everyone Is A Teacher Here of Strategy, Motivation to learn.

Abstrak: Permasalahan penelitian ini adalah Apakah Ada Pengaruh Strategi Everyone Is A Teacher Here terhadap Motivasi Belajar Siswa Kelas XI di SMK Muhammadiyah 04 Medan T.P 2016/2017. Tujuan penelitian ini adalah untuk mengetahui pengaruh Strategi Everyone Is A Teacher Here terhadap Motivasi Belajar Siswa Kelas XI Di SMK Muhammadiyah 04 Medan T.P 2016/2017 yang berjumlah 211 Siswa yang terdiri dari 6 kelas dan terbagi dalam 3 jurusan dan sampel yang diteliti adalah kelas XI AK 2 SMK Muhammadiyah 04 Medan sebanyak 38 siswa. Instrument yang digunakan adalah angket dan tes. Yang mana angket ini melakukan pengamatan di SMK Muhammadiyah 04 Medan untuk mengetahui motivasi belajar siswa. Metode yang digunakan dalam penelitian ini adalah metode kuantitatif dengan unit analisis Product Moment. Dari hasil penelitian ini dapat dilihat peningkatan motivasi belajar siswa dengan menggunakan pengaruh Strategi Everyone Is A Teacher Here pada mata pelajaran Pendidikan Kewarganegaraan dengan penelitian yang dilakukan, maka ditemukan bahwa pembelajaran Everyone Is A Teacher Here berpengaruh terhadap motivasi belajar siswa pada mata pelajaran Pendidikan Kewarganegaraan. Dari hasil perhitungan hipotesis diperoleh $t_{\text {hitung }}=2,309$ sebesar taraf signifikan $\alpha$ $=0,05$ dan $d k=n-2=38-2=36$, maka diperoleh harga $r$ tabel $=1,6892$. Diperoleh $t_{\text {hitung }} 2,309>t_{\text {tabel }}$ 1,6892, ini berarti Ha diterima artinya adanya pengaruh yang signifikan antara strategi Everyone Is A Teacher Here terhadap motivasi belajar siswa.

Keywords: Strategi Everyone Is A Teacher Here, Motivasi Belajar Siswa 


\section{PENDAHULUAN}

Pendidikan dalam sejarah peradaban manusia adalah komponen penting yang erat dan tidak terpisahkan dari perjalanan hidup manusia. Pendidikan dalam sehari-hari telah dijalani oleh manusia baik secara sadar maupun tidak sadar. Kegiatan yang dilakukan oleh manusia untuk mencapai suatu tujuan merupakan bagian dari pendidikan. Pendidikan dapat berlangsung melalui pendidikan informal, pendidikan nonformal dan pendidikan formal seperti sekolah serta institusi lainnya.

Pendidikan Kewarganegaraan dapat diartikan sebagai wahana maupun wadah untuk mengembangkan dan melestarikan nilai luhur dan moral yang berakar pada budaya bangsa Indonesia yang diharapkan dapat diwujudkan dalam bentuk prilaku kehidupan sehari-hari peserta didik sebagai individu, anggota masyarakat dalam kehidupan berbangsa dan bernegara. Peranan pendidikan merupakan hal penting bagi proses peningkatan kemampuan dan daya saing bagi suatu bangsa di mata dunia.

Pendidikan formal merupakan jenjang pendidikan dan pelatihan untuk mempersiapkan Sumber Daya Manusia (SDM) yang berkualitas. Salah satu mata pelajaran yang diberikan di pendidikan lanjutan tingkat menengah adalah Pendidikan Kewarganegaraan yang bertujuan untuk menciptakan karakter pada diri peserta didik sehingga menjadi manusia yang bermoral dan beradab yang sangat diharapkan agar peserta didik dapat memahami dan menjalankan karakternya dalam kehidupan sehari-hari. Namun harapan ini belum semuanya dapat dicapai, tergantung dari hasil belajar peserta didik tersebut.

Berdasarkan hasil observasi dan wawancara sementara dengan salah satu guru PKn kelas XI SMK MUHAMMADIYAH 04 MEDAN, diperoleh informasi bahwa motivasi siswa dalam pelajaran Pendidikan Kewarganegaraan masih rendah. Hal ini dapat dilihat dari respon siswa terhadap proses pembelajaran yang dilakukan oleh guru tersebut kurang menarik perhatian dan minat siswa sehingga sebagian tidak termotivasi dan siswa ada yang memiliki nilai dibawah rata-rata. Dan ada salah seorang siswa yang mengaku bahwa ia kurang tertarik dan terkesan membosankan terhadap pelajaran Pendidikan Kewarganegaraan sehingga ia juga tidak bersemangat dalam mengikuti proses pembelajaran tersebut.

Dari data di atas dapat diperoleh bahwa masih banyak siswa yang hasil belajar Pendidikan Kewarganegaraan dibawah KKM yang ditetapkan oleh sekolah. Hal ini menunjukkan bahwa hasil belajar Pendidikan kewarganegaraan masih perlu ditingkatkan dengan cara memotivasi siswa agar lebih giat dan semangat lagi dalam pelajaran Pendidikan Kewarganegaraan.

Salah satu alternatif yang ditempuh dalam mengatasi hal tersebut yakni untuk mengaktifkan motivasi belajar siswa adalah dengan menerapkan strategi pembelajaran Everyone Is A Teacher Here (Setiap Orang adalah Guru). Strategi ini merupakan salah satu pembelajaran yang dalam pelaksanaannya setiap siswa bisa mengeluarkan pendapatnya dalam berbagai perspektif dari pertanyaan atau masalah yang diajukan. Kegiatan ini merupakan sebuah teknik untuk merangsang diskusi dan mendapatkan pemahaman lebih mendalam tentang berbagai isu kompleks. 
Strategi ini sangat tepat untuk mendapatkan partisipasi kelas secara keseluruhan dan secara individual. Strategi ini memberikan kesempatan kepada setiap siswa untuk berperan aktif sebagai guru bagi siswa lainnya. Siswa memberikan penjelasan atas pertanyaan yang didapatkan siswa tersebut dari siswa lainnya di depan kelas sehingga siswa lain menangkap maksud atau ide yang disampaikannya.

\section{METODE}

Metode yang digunakan dalam penelitian ini adalah metode kuantitatif dengan unit analisis Product Moment. Keseluruhan populasi ini ditujukan pada siswa kelas XI yang berjumlah 211 orang, sampel berjumlah 38 orang. Instrumen yang digunakan adalah Angket. Data dianalisis dengan uji$t$.

\section{HASIL}

Uji hipotesis dalam penelitian ini menggunakan uji t yang mana jumlah sampelnya untuk tiap kelas adalah sama yaitu kelas kontrol dan kelas eksperimen masing-masing berjumlah 38 siswa dan nilai pre test dan post tes bersifat homogen. Berdasarkan tabel dan hasil perhitungan diatas, maka disimpulkan bahwa $t_{\text {hitung }}>t_{\text {tabel }}$ dan dapat dilihat bahwa motivasi belajar sebelum menggunakan strategi pembelajaran Everyone Is A Teacher Here sebesar 2,695 > 1,9958 dan motivasi belajar sesudah menggunakan strategi pembelajaran Everyone Is A Teacher Here lebih meningkat menjadi sebesar 3,808 > 1,9958. Untuk mengetahui lebih lanjut apakah ada pengaruh antara variabel X (Strategi Everyone Is A Teacher Here) dengan variabel Y (Motivasi Belajar) maka terlebih dahulu mencari koefisien korelasi product moment.

Berdasarkan tabel hasil perhitungan diatas dimana nilai $t_{\text {hitung }}>t_{\text {table }}$ yaitu 2,309 $>1,6892$, maka uji hipotesis dalam penelitian ini diterima. Jadi karena $\mathrm{H}_{0}$ ditolak dan $\mathrm{H}_{\mathrm{a}}$ diterima maka motivasi belajar siswa sesudah menggunakan strategi Everyone Is A Teacher Here lebih baik dibandingkan menggunakan pendekatan konvensional dengan metode ceramah. Berdasarkan hasil perhitungan diatas maka strategi Everyone Is A Teacher Here memberikan pengaruh sebesar $12.8 \%$ terhadap motivasi belajar siswa, sedangkan 87,2 pengaruh dari variabel lain diluar variabel motivasi belajar siswa yang tidak teramati dalam penelitian ini. Dari analisis data telah terbukti bahwa terdapat pengaruh yang signifikan antara strategi pembelajaran Everyone Is A Teacher Here terhadap motivasi belajar siswa kelas XI AK 2 SMK MUHAMMADIYAH 04 MEDAN. Hal ini ditunjukkan dengan korelasi yang diperoleh dari perhitungan korelasi product moment $\left(\mathrm{r}_{\text {hitung }}=0,358>\mathrm{r}_{\text {tabel }}=0,325\right)$ dan $\left(\mathrm{t}_{\text {hitung }}=2,309 \geq \mathrm{t}_{\text {tabel }}=1,6892\right)$

\section{PEMBAHASAN}

Tujuan penelitian ini adalah untuk mengetahui bagaimana pengaruh yang signifikan antara strategi pembelajaran Everyone Is A Teacher Here terhadap motivasi belajar siswa kelas XI AK 2 SMK 
MUHAMMADIYAH 04 MEDAN T.P. 2016/2017. Dalam hal ini diketahui jelas bahwa strategi pembelajaran Everyone Is A Teacher Here merupakan strategi yang mampu mengaktifkan dan memotivasi siswa dalam belajar dimana kadang kala siswa merasa jenuh, ngantuk dan takut dalam menyampaikan aspirasinya kepada guru ataupun sesama teman lainnya. Tujuan dari strategi pembelajaran Everyone Is A Teacher Here adalah untuk memotivasi dan meyakinkan siswa agar lebih berani dalam menyampaikan pendapatnya dengan cara berani berbicara langsung di depan guru maupun temannya yang lain. Selain itu juga diharapkan siswa mampu menerima kenyataan bahwa menyatakan atau menegaskan diri adalah tindakan yang layak atau benar serta menambah wawasan.

Motivasi belajar adalah prilaku yang dilakukan oleh seseorang yang dapat merangsang dirinya untuk melakukan sesuatu yang berguna untuk mencapai suatu tujuan tertentu dengan cara melakukan halhal yang positif.

\section{SIMPULAN}

Berdasarkan hasil penelitian dan pembahasan maka dapat disimpulkan bahwa strategi Everyone Is A Teacher Here lebih baik dan lebih efektif dibandingkan pendekatan konvensional dengan metode ceramah terhadap motivasi belajar siswa kelas XI AK 2 di SMK MUHAMMADIYAH 04 Medan T.P 2016/2017. Kesimpulan dari hasil penelitian ini dirincikan sebagai berikut: Dari hasil uji hipotesis (t) menunjukan motivasi belajar siswa sebelum menggunakan strategi Everyone Is A Teacher Here ada perbedaan antara kelas kontrol dan kelas eksperimen ditunjukan bahwa 2,965 $>1,9958$ atau $t_{\text {hitung }}>t_{\text {table. }}$. Dari hasil uji hipotesis ( $\mathrm{t}$ ) menunjukan motivasi belajar siswa setelah menggunakan strategi Everyone Is $A$ Teacher Here ada perbedaan antara kelas kontrol dan kelas eksperimen ditunjukan bahwa 3,808 > 1,9958 atau $t_{\text {hitung }}>t_{\text {table. }}$.

Dari hasil uji hipotesis (t) menunjukan adanya pengaruh antara strategi Everyone Is A Teacher Here dengan motivasi belajar siswa kelas eksperimen ditunjukan bahwa 2,309 $>1,6892$ atau $t_{\text {hitung }}>t_{\text {table. }}$. Koefisien korelasi product moment, berdasarkan hasil data tersebut maka strategi Everyone Is A Teacher Here memberikan pengaruh sebesar $12.8 \%$ terhadap motivasi belajar siswa, sedangkan 87,2 pengaruh dari variabel lain diluar variabel motivasi belajar siswa yang tidak teramati dalam penelitian ini. 


\section{DAFTAR RUJUKAN}

A.M. Sardiman. 2004. Interaksi dan Motivasi Belajar Mengajar. Jakarta: Raja Grafindo Persada Abubakar, Suardi. Dkk. 2007. Kewarganegaraan 2 Menuju Masyarakat Madani. Jakarta: Yudhistira Margono, S. 2013. Metodologi Penelitian Pendidikan. Jakarta: Rineka Cipta Nasution, Irwan. 2014. Ilmu Pendidikan. Jakarta: Rineka Cipta

Rangkuti, Ahmad Rizal. 2014. Statistik Untuk Penelitian Pendidikan. Bandung: Citapustaka Media Sabri, Ahmad. 2010. Strategi Belajar Mengajar. Jakarta: Quantum Teaching

Sanjaya, Wina. 2008. Strategi Pembelajaran. Jakarta: Kencana

Silberman, Melvin L. 2007. Active Learning: Strategi Pembelajaran Aktif. Yoyakarta: Insan Madani Sobur, Alex. 2003. Psikologi Umum. Bandung: Pustaka Setia

Sudjana, Nana. 2002. Metoda Statistik. Bandung: Tarsito

Sudjiono, Anas. 2009. Pengantar Statistik Pendidikan. Jakarta: Rajawali Pers

Sugiono. 2007. Metodologi Penelitian Pendidikan. Jakarta: Rineka Cipta 2012. Metodologi Penelitian Pendidikan. Jakarta: Rineka Cipta 2013. Metodologi Penelitian Pendidikan. Jakarta: Rineka Cipta

Suharsimi, Arikunto. 2006. Metode Penelitian Pendidikan. Bandung: Alfabeta

Suprijono, Agus. 2009. Cooperative Learning Teori dan Aplikasi Paikem. Yogyakarta: Pustaka pelajar Syah, Muhibbin. 2010. Psikologi Pendidikan dengan Pendekatan Baru. Bandung: Remaja Rosdakarya Uno. Hamzah B. 2018. Model Pembelajaran. Jakarta: Bumi Aksara

Bumi Aksara 2006. Teori Motivasi dan Pengukurannya: Analisis dibidang Pendidikan. Jakarta: 